JOANNA LUDWIKA PĘKALA

Forum Pedagogiczne

Wydział Pedagogiczny

9 (2019) 2, cz. 2

Uniwersytet Warszawski

Wpłynęło: 30.06 .2019

ORCID ID: oooo-0003-4554-1962

Zatwierdzono do druku: 20.11.2019

DOI: $10.21697 / f p .2019 .2 .42$

WIKTORIA KOWALSKA

Wydział Pedagogiczny

Uniwersytet Warszawski

ORCID ID: 0000-0002-3560-0677

\title{
LEADERSHIP IN EDUCATIONAL INSTITUTIONS: SHARED DUTY AND JOINT RESPONSIBILITY
}

\begin{abstract}
In the present world changes are inevitable and modern schools will also be subjected to them. School principals should, therefore, aim at transforming the institutions into learning organizations, thus gathering people capable of self-reflection and self-improvement. The purpose of this article is to prove that in order to achieve measurable and sustainable success in an educational institution, leadership must be shared bythe principal and the teachers. The ability to diagnose the situation of the institution is also important, as is the drawing of constructive conclusions from the introduced changes, both those successful and those unsuccessful. Knowledge of possible leadership styles can be an inspiration in search for effective solutions in educational practice for headteachers, teachers and external experts who provide support to schools in the process of change.
\end{abstract}

Keywords: school leadership; educational management; headmaster/principal; teacher; learning organization.

\section{Introduction}

The authors who research the concept of management point to both the ambiguity of the term and to the differences in definition of the discussed category which stem from the diversity of fields it is related to. They emphasize that management in education should not be treated as one of many types of management - a type that is carried out in distinct conditions, to be specific in the context of education. (Rosalska, 2016 p. 108-109; Dorczak, 2018, p. 45) This is a separate category that possesses its own characteristics, circumstances and which requires a distinct way 
of defining. In any organization, regardless of the specifics of their operation, we deal with constantly running processes. They are formed by relations between people as well as procedures in the course of action of the organization, which undergoes constant changes. The leader of this change should be a head teacher, whose role is to establish a team of teachers who support his or her leading position. What is more, teachers should become competent managers and leaders for their co-workers, the student community and also parents.

\section{Leadership of headteachers}

Educational leadership concentrates on the processes related to learning and development. Leaders not only constantly learn and expand their qualifications but also provide those around them with an opportunity to learn at the same time. This requires proper competencies that enable the organization of that process and provide necessary resources. There is a distinction between the terms of management and leadership in the professional literature. Considering the first of those concepts as more formal, technocratic and systemic, and the other one as more informal, social and individual helps to make the typology more comprehensible. This problem can be looked at as a correlation, where leadership is essential for achieving systemic results. (Szafran, 2013, p. 85)

The difference between leadership and management were defined among others by John Kotter (1995, p. 99-115) who pointed out why those two processes should be maintained in a balance. Kotter proved that only those organizations that are able to achieve this state can develop properly. In such institutions teams get results in the form of achieving organizational goals, they have a high level of intrinsic motivation, they also present numerous ideas for solving problems.

Another aspect revealed by the author is that many organizations are characterised by excess of management and too little leadership. In a classic distinction of those terms it can be argued that strong leadership paired with weak management can have worse results than the opposite case. Ergo combining strong leadership with strong management and balancing those two can pose a great challenge. According to Kotter (1995, p. 100), management is connected with complexity of actions, whereas, leadership means coping with the processes of constant changes. Change is a fundamental part of leadership and a leader, in opposition to a manager, can be characterised as more oriented towards changes and their implementation. Leader, additionally, is required to be competent at teamwork, and that is what makes him (Kotter calls him the leader of changes [1995, p. 101]) different from a manager in a traditional sense. However, professional publications more and more frequently mention the term professional manager, whose characteristics assume that leadership and management should constitute patterns of complementary behaviours, knowledge and skills. An ideal solution would be for a contemporary 
manger of education to be also an expert leader. (Madalińska-Michalak, 2014 p. 16-17)

Concerning education Grzegorz Mazurkiewicz (2012, p. 35) emphasises that managerial responsiveness and self-criticism are necessary traits for a headmaster to be called an educational leader. He claims that the function of school principal can be performed well only with a high level of self-awareness, adequate self-esteem and conviction about being the right person for the post. Only then stepping back and giving the staff space to work, grow and achieve success will be a natural prodevelopmental decision of a headteacher. Educational leaders should share their authority and encourage others to be active participants by helping them believe in themselves.

\section{Professional requirements for headteachers and leadership}

With challenges of global society educational leadership is faced with ambitious tasks of understanding the present, approaching it with criticism and planning adequate processes. School and other educational institutions ${ }^{1}$ operate, the same way as all social and economical organisations do, in an unpredictable and unstable reality. (Mazurkiewicz, 2015, p. 17)

Headteachers are usually perceived through the prism of competencies they should posses, their sense of mission that should serve as a guideline for everyday decisions and quality of their work, colloquially known as achievements that can be displayed and which are assessed by supervisory authorities and local community. They closely observe and keep track of all missteps and wrong decisions. Seldom are those mistakes analyzed from the angle of available resources and external assistance provided to a headteacher. Jacek Pyżalski (2015, p. 196) emphasises that if the topic of support is discussed at all, headteachers are mostly seen as providers to teachers, other staff, parents, students and representatives of local community. The position of a headteacher is counted among social and assistance professions, underlining the unique properties of this job- the quality of work and the responsibility for coordination of work of other assistance professions, like teachers, pedagogues, psychologists, etc. (Moreira, Rivero \& Alonso, 2018, p. 2).

Vocational requirements for all helping professions focus on a few major points:

- social exposition,

- inevitability of making crucial decisions under pressure,

- permanent communication and close interpersonal exchange with multiple interlocutors,

1 Using the term educational institution here the authors mean mainly schools. However, leadership in other types of educational institutions as kindergartens, day-care centres, social prevention and resocialization institutions, cultural centres for children have also some similar characteristics. 
- major responsibility at legal and psychological level,

- necessity of tempering emotions to the requirements of the job,

- significant disproportion between 'giving and taking',

- using personality as a tool for work. (Pyżalski, 2015, p. 196)

The last of the listed components is especially strongly present in the work of headteachers. If we separate administrative tasks from the ones connected with managing teams and collaborating with local community, it may occur that personality traits have a casting vote on whether a headteacher can become a leader.

Managers in prominent companies or corporations are well prepared for taking up managerial position. Very often they learn for years- take part in training courses on soft competences, efficient communication, working time organization, managing teams, dealing with difficult customers or coping with stress. Before they resume their posts, they usually receive multiple promotions, and the competencies they acquire during that process, in correlation with individual character traits, help them become professional leaders within the organizations. In comparison, tasks for a head of school are similar. Nevertheless, apart from a few examples, a headteacher has to manage without the support mentioned above, very often battling against unreasonably high expectations caused by being promoted from the environment of his or her colleagues - other teachers.

Grzegorz Mazurkiewicz (2015, p. 18) emphasises that educational leaders in Poland exist in a specific void- there are no set standards for their work, the discourse language is non-existing, there are no specified values to follow, no one has established any list of tasks of leaders, and the number of things they are asked to do is absurd, making it impossible to carry out their duties in the law - abiding way. Therefore, the role of a head of school requires a new definition which should concentrate on the process of learning and growth of students and teachers. It is also necessary to work out a common understanding of the role of a headteacher and the list of competencies necessary for its execution as well as values that we want to refer to in education. It is worth mentioning at this point that some of the actions performed by headteachers can be major stressors for teachers. It also means that growing frustration of the headteacher will affect the work of teachers, and in consequence, all crucial processes running at school. Population-based studies conducted on teachers clearly point out that out of eight most burdening psycho - social elements of working environment two are directly linked to actions (or their lack) of a headteacher. It stems from the fact that teachers feel they have very little influence on what is happening at school and from the lack of support from the superiors. (Pyżalski \& Merecz, 2010, p. 53-74)

\section{Headteacher: efficient ruler, manager and leader in educational environment}

Development of an educational institution, apart from the scope of didactics and education, should include the field of school management; in other words, engage 
competence of those who manage. The advocated solutions point to the imminent role of leadership and its beneficial influence on running a school, aiming to further engage the whole community to help with issues and challenges that arise at school. Bożena Tołwińska (2011, p. 105-107) emphasises that the variability and dynamics of the environment require the staff to be involved in the decision-making processes. As it has been mentioned before, a headteacher is expected to possess highly developed managerial skills and social conscience, so he or she can make good decisions and perform effectively at many levels. Therefore, education is in need of leaders who, on the one hand are able to see school as a learning organization, and on the other hand are responsive to each and every of its members, getting them to cooperate.

Joanna Madalińska-Michalak (2014, p. 18) emphasises that it is impossible to reorganize the school while underestimating the role of a leader. Without innovative approach to management, centred on the potential of the employees and leading role of the headmaster, there will be no success, neither personal nor institutional. A headteacher, whose duty is to introduce new ideas at school, should be responsible for making school faculty accept new, innovative solutions as well as engaging new members in accomplishing tasks. Rafał Mrówka (2001, p. 9) stresses that establishing own credibility is a foundation for achieving success as a leader, the atmosphere at work and level of trust between members of a team are not without significance as well.

In the discourse on implementation of changes arises a question whether it is proper to have a headteacher, who is also a formal head of school, to be a leader of transformation. It is possible to present numerous arguments for and against such a claim. Nevertheless, probably most experts would agree that introducing thorough changes requires professional intuition, decision-making powers, authority and devotion of managers being essential to the process. In consequence, the changes are imperative, the process itself as well as its effects are internalized more quickly, and ultimately burdened with minor costs. (Madalińska-Michalak, 2014, p. 9) However, if headteachers are not responsible for the implementation of changes, it is important that they remember that the support of acclaimed and credible authorities strengthens the trust of members of an institution in the forthcoming process; it also boosts the level of optimism and makes them anticipate the success of the endeavour. Support of a leader is indispensable to the overcoming of inertia and fear of failure. A head, especially in education, should be responsible for creating suitable environment for both creative exploration of new ideas and making an effort of the whole process of implementing changes. The attitude of a leader usually serves as a role model for other employees- a model on which they shape their own demeanour. (Mrówka 2001, p. 13)

Andy Hargreaves and Dean Fink came up with an idea of a well-balanced leadership while they were studying the role of leaders on building up capacity of the school. Authors have put forward a thesis that each school has to work out 
its own working style, which is not only based on the educational policy directives, but allows for independent actions and thinking. It is important for the change to be adequate to the conditions and capacity of the educational institution as well as be accepted by the teachers. (Mazurkiewicz, 2012, p. 8) Witold Kołodziejczyk (2012, p. 172) points out that the success of a school is determined by its employees, but it heavily depends on the headteacher whether there are conditions in which ingenuity, creativity and commitment of the teachers can be recognized, appreciated and properly used.

\section{Leadership of teachers}

In the previous chapter a huge part was devoted to the tasks of a headteacher. His role is inextricably linked to the the functions assigned to teachers. Here arises a fundamental question: do teacher duties include ones related to leadership? On the one hand an affirmative answer seems obvious- the number of responsibilities of a headteacher forces him to share some of them with the staff. However, delegation of tasks is not the only reason why teachers lead (manage people and processes) in education.

\section{Basic characteristics of teachers' leadership}

First, we should think about the groups that are under the guidance of teachers. Students and parents are the main beneficiaries that make use of services provided by school, and what follows, by the representatives of the teacher profession. All three participants in this triad (teacher-parent-student) communicate with each other, which confirms the first out of three features of leadership listed by Roman Dorczak (2018, p. 47) who understands leadership as a relation and social process. Difficulty in communication between the teachers and the other two groups - students and their parents, is complex. Usually, teachers communicate with one of the aforementioned groups at a time. Nevertheless, we should take under consideration the difference in age, experience and needs of both parties. Each of the collectives perceives the teacher in a different way, and each is perceived in a different manner in return. In addition the whole process is complicated (but also enriched) by communication of the teacher with individuals. A meeting between a teacher and a student can become a conversation between two people. The same goes for the parents, and it is best if this kind of interpersonal exchange is not limited to talking about educational difficulties only.

The process of communication should enable people to forge relationships as individuals and as a group. There is a notion, stemming from the reflexion on the topic, that leadership of teachers is fulfilled in relation and through communication. Nevertheless, or because of that it is not an easy task. All subjects of this relation have specified expectations. Students, depending on their age, are 
looking for a caretaker, a friend, a confidant or, if the relation is distorted, they might see the teacher as a part of the system of penalties and awards (marks). Today, expectations of parents directed towards teachers are those of a didactic nature not only substantive but also methodological. (Pękala, 2017, p. 93-97) Therefore, expectations of both parties can differ immensely, and if we take into account the needs of a teacher - the disparity can affect the relation between the two, and eventually the execution of leadership of the teacher.

This kind of issues require cooperation of all the staff, and here is the second feature of leadership according to Roman Dorczak (2018, p. 47) - sharing the authority among many members of an institution such as school. Other employees can give advice, substantive guidelines, sometimes a direct help in resolving conflicts. This kind of support is essential at school, especially if it is located in a highly demanding social environment (e.g. where many families with low socioeconomic status live); nevertheless, it is found at all schools.

The fact that the quality of relations between employees is important in any institution, not only educational one, is emphasized by the professional literature on management. At present the communication skills of employees of different professions and positions are being trained. This phenomenon can be interpreted as either an outcome of noticeable deterioration of cooperation in working environments, or just rebirth of interest in the influence of interpersonal relations on professional involvement of people. However, especially in an educational institution, where the diversity of relations is so wide, the issue of working out satisfactory associations between staff members is immensely compelling. Julianne Wenner and Todd Cambell (2017, p. 155) have proven in their paper that teachers can encounter many obstacles in the realisation of their leadership at school. However, poor relations with the administrators and the rest of staff is the biggest of them. It is also difficult to fulfill the leaders' duties when the principals are not supportive and do not give their employees (lead teachers) enough autonomy.

The somewhat professional understanding between professionals in the educational institution creates school climate wherein relations between teachers and students (and also their parents) are secondary. Why is the correlation presented like this by the authors? The teachers who feel supported and safe in their workplace are able to create the same atmosphere in a classroom. (Petlak, 2007, p. 40-45) Of course, there are those who, in spite of the limitations, try to provide students with environment for growth and learning, but they have to put disproportionate amount of work and energy into that. Positive school climate encourages development of all participants of educational processes; it facilitates carrying out leadership tasks by teachers, such as settling disputes. All interpersonal relations (especially within such a huge collective of people) can cause misunderstandings or discrepancies of expectations, plans and needs. This is where we can introduce the next feature of leadership in education which is connected to the implementation of shared 
values. On the one hand, they regulate relationships, on the other hand they can cause conflicts.

The issue of fundamental values in educational leadership - the third feature mentioned by Dorczak (2018, p. 48) seems to represent the issue of principles in education in general. Again, the term is present in other fields but educational perspectives provides specific character to it. In the context of education communication takes on the form of deep, humane dialogue, it expresses itself by a certain demeanour, and the leadership bears the characteristic of a duty (in the meaning of serving others). There is a similar situation with values which, according to Henryk Elzenberg, "do not constitute any quality, neither in themselves, nor in other objects. [Value] is a fact which proves that the object is the way it supposed to be [...] it is a convergence between the actual and proper state of an object." (as cited in Pękala, 2017, p. 28) This definition seems to be complete, but it might call into question who should be the person to decide on the state of, "propriety" of specific values in education and to be responsible for sustaining convergence between reality and propriety. Here lies an actual, communicative, relational character of leadership in education - imposing values very often leads to an argument, on the other hand choosing them together might lead to a meeting of minds. It is not really about including students in the process of establishing rules for classroom-work (although it is a way to make them cooperate while working on a list of rules). School is a place for "transfer" of values, and the term is not put in inverted commas by accident. It is not about regular transfer but about co-creating in a relationship, in reality of life, according to the philosophy of Non scholae, sed vitae discimus. It is about discovering values together through solving disagreements by participants of educational processes.

From the perspective of school values are not rules, but they are something closer to educational objectives. Kazimierz Denek (1999, p. 60-61) calls attention to that link; he states that gaining knowledge and skills, developing interests and cognitive abilities should derive from values. He also adds that in order to achieve values in education one should start with the objectives - actions taken for the sake of achieving the objectives will help achieve the values. In other words axiology is important in education, and it is the starting point for managing the process of education. Objectives point out what to teach and learn, what to do for the whole process to be worthwhile from the psychological and ethical point of view. Finally, what to do to make the values passed down directly through the material, and indirectly through the methods, become internalised by the student. ${ }^{2}$

2 According to Lawrence Kohlberg a person goes through the consecutive stages and levels of moral understanding. In the early stages, there exists a dominant need for avoiding punishment, getting a reward or earning favour of authority (pre-conventional and conventional morality). In later stages (if the development of a person does not come to a stop) there is a deeper internalization 
What stems from the reflexion until this point is that the leadership of teachers in education happens through relations where communication serves as its tool. Relationship is forged via cooperation and for cooperation with all subjects of education (teachers, parents and students, as individuals and as a group). The basis for interaction, or more broadly - relationship, are values established and used for cooperation. All those components are of a processual character they are not permanent, they come to being and then transform. That is probably why school, or in a broader approach any educational institution, is described as a learning organisation.

\section{Teacher - leader of a learning institution}

Lack of stability of the market mentioned by Magdalena Gorzelany-Dziadkowiec is not a concern to businesses only. Potential candidates for teachers are recruited from their local environment, which has changed significantly throughout the years since the first mentions of the information society. Therefore, expectations placed upon teachers are completely different now from the ones of several years ago. (Pękala, 2017, p. 98-102) Life -long learning has become an intrinsic part of our reality and it concerns everyone regardless of the profession or life circumstances. The concept of life-long learning has evolved in a way, first starting as a postulate, then a wishful concept and finally the propriety, in some professions it has even become a necessity. That also, or even especially, concerns the teacher profession. The evolution was caused by the change of status of information. In the past it used to be a permanent component of a stable system of knowledge, where any changes were rare and special, and even presented something festive. At present changes are inherent and anticipated elements of reality, and the way information is managed allows to determine whereas leadership is successful or even deliberate.

Although, the term information is broadly used, it is usually defined in the language of science, which is unintelligible for many users of that term ${ }^{3}$. In consequence, it seems that uncovering the discrepancy between knowledge and information contributes more to the debate. The intrinsic feature which allows for distinguishing those two categories is the fact that, in the case of information, there is no place for interpretation (Stefanowicz, 2010, p. 21). What is worth mentioning here is the next task of a teacher as a leader: helping with interpretation, which is nothing more than the reinforcing of learning process, and in consequence developing thinking. The authors postulate that there is a close connection between

of rules, which turn into personal values. The person behaves in a way that will benefit the general public, his or her aims are not solely particularistic (Zimbardo \& Gerrig, 2012, p. 459).

3 Example of a definition of information by Jadacki and Brożek: „If subject y received a statement from $\mathrm{z}$ which declared existence of fact $\mathrm{p}$ and is convinced that $\mathrm{p}$ is genuine, then $\mathrm{y}$ obtained information that $\mathrm{p}$ is happening" (Stefanowicz, 2010, p.15). 
learning and teaching (Dylak, 2009, p. 28; Kupisiewicz, 2005, p. 23) and they suggest that the most valuable education is teaching without imposing teacher's interpretations. This sort of schooling requires from educators the practice of lifelong learning, especially to train their skills (soft competencies and methodology in particular), which should in consequence result in the cultivation of their interpretative skills (e.g. Kwaśnica, 2003; Kwiatkowska, 2008). A teacher who is constantly updating and widening his or her knowledge and is changing his or her position from managerial role to the supportive one, cannot be passive and surrender to the flow of information especially because of his role of a leader, both in classroom and local environment. The ability to accommodate leader duties with providing opportunities for learning by giving information, arranging environment, offering modifications and also encouraging autonomy of all subjects of education, is what makes a teacher a transformative intellectual (Kwiatkowska, 2008, p. 3940), which is possible due to his interpretative skills. This type of competencies are useful to a teacher because, on one hand they enable constant self-reflection, and on the other, they are useful for helping students with the interpretation of the immense amount of information they encounter. The actions of a teacher described here might seem to be the opposite of what his or her leadership role entitles to, however, it only shows how complex the situation is. A classroom and a school community are mainly created by a teacher. He is in charge of a group of people, each with specific features, who are unique. The same educator also guides the parents of students while arranging class life, which is an intrinsic element of school life. These actions should reinforce the school as a learning organization ${ }^{4}$. In order to expand the reflection on the influence of leadership of teachers on this type of institution, it is worth to mention the features of a developing organization, which include:

- constant enhancement of employee development,

- promoting teamwork and friendly work environment,

- supporting different learning styles of all,

- adaptability to change,

- proficiency in acquisition and creation of knowledge as well as behaviour modification in connection to the process,

- extreme flexibility and responsiveness (lack of routines, habits and stereotypes),

4 The authors of this paper would like to emphasise that while it would be valuable for every educational institution to be a learning organization, not every of them is. It follows that the terms educational institution and learning organization are not identical. These organizations differ in the style of management, philosophy of teaching and learning, and mainly in the understanding of what the development is. 
- becoming an organization which is constantly changing, a place for intellectual growth of the employees. (cf. Magdalena Gorzelany-Dziadkowiec, 2015, p. 11)

All of the aforementioned features of an organization can be also used to describe the competencies of a teacher-leader. Managing a class of people requires coping well with changes and stress, but most of all, it requires flexibility and fast reactions. It is not enough for a teacher to be open to new concepts. He has to gain, create and co-create knowledge with his students by using activating methods. To do that, he should conduct in-action research with his students and then research the action (Kwiatkowska, 2008, p. 215-228), the results of which will be an extension of self-reflexion, that is vital to a leader. The analysing of own knowledge, drawing conclusions from experience, adjusting own cognitive structures with regard to the perception of new information - the whole process repeated again and again can form the teacher's reflexion on the shape of his or her own leadership. These are skills and processes also described by aforementioned Wenner and Cambell (2017, p. 148-150) as indispensable elements of professional lead teacher's preparation.

There are two other groups of people who are subjects to the leader role of a teacher, namely the co-workers and parents of students. In each modern school there should be an institutional learning process regarded in three steps as the flow of information, its interpretation and the response to all data coming from within and from the outside of the institution. (Gorzelany-Dziadkowiec, 2015, p. 30) In the light of this definition, the encounters of the aforementioned participants of education comprise data exchange and co-creating knowledge. This supports the hypothesis for the role of communication in the leadership of teachers.

Therefore, lifelong learning, using modern methods, the examination of own professional activity and self-education are decisive factors which constitute a teacher as a person who co-creates school as a learning organization. He/she is a subordinate who shares managerial tasks with a headteacher or does some other leader-related tasks for school. The success of this process is heavily dependent on the conditions of work and intellectual growth of the staff, organized by the head teacher, as well as the results of their collaboration.

\section{Summary}

Educational leadership of headteachers and teachers deal with processes of cooperation and management. Sustaining those both components in the state of equilibrium is not an easy task, it can also be found among other requirements demanded from leaders of education at school. The fact that headteachers have authority does not exclude other teachers from executing leadership tasks; on the contrary, it enables them to do it.

The process of education is enriched by the personalities of its subjects, which serve as important tools for educational work, and also for leadership itself. 
It depends on the personality traits but also on the training that includes soft competencies which are extremely important in this kind of job, if it is satisfactory and efficient.

Demands that leaders, headteachers and teachers face are numerous and come from various social groups. The discrepancy in expectations makes it harder to satisfy each of them, thus forcing the staff to cooperate, and in a way causes an improvement of the whole organization and its members. The main reason for that is fact that today leadership is constituted by managing information and coping with change. The execution of those two processes, by a headteacher, is dependent on the overall proper ambience of the team. Benevolence and support given to the employees by the management facilitate communication, create the school atmosphere. Such ambience can be found only when the headteacher is not overloaded and the leadership is shared in the educational institution. In effect that division of duties can bear the fruit in the form of a harmoniously functioning establishment.

\section{References}

Denek, K. (1999). Aksjologiczne aspekty edukacji szkolnej. Toruń: Adam Marszałek. Dorczak, R. (2013). Dyrektor szkoły jako przywódca edukacyjny - próba określenia kompetencji kluczowych. In G. Mazurkiewicz (Ed.). Przywództwo i zmiana w edukacji. Ewaluacja jako mechanizm doskonalenia. Kraków: Wydawnictwo Uniwersytetu Jagiellońskiego.

Dorczak, R. (2018). Znaczenie przywództwa nauczycieli w przywództwie edukacyjnym. In J. Madalińska-Michalak (Ed.). Przywództwo nauczycieli. Warszawa: FRSE.

Gorzelany-Dziadkowiec, M. (2015). Organizacje uczace się. Teoria i praktyka. Kraków: Wydawnictwo Uniwersytetu Ekonomicznego.

Kordziński, J. (2015). Dyrektor szkoły - moderator, facylitator, coach. Warszawa: Wolters Kluwer.

Kotter, J. P. (1995). The new rules: how to succeed in today's post-corporate world. New York: The Free Press.

Kupisiewicz, Cz. (2005). Podstawy dydaktyki. Warszawa: WSiP.

Kwaśnica, R. (2003). Wprowadzenie do myślenia o nauczycielu. In Z. Kwieciński \& B. Śliwierski (Ed.). Pedagogika. Warszawa: PWN.

Kwiatkowska, H. (2005). Tożsamość nauczycieli. Gdańsk: GWP.

Kwiatkowska, H. (2008). Pedeutologia. Warszawa: Wydawnictwa Akademickie i Profesjonalne.

Kwiatkowski, S. M. (2010). Miejsce i rola w przywództwie edukacyjnym. In: S. M. Kwiatkowski, J. Madalińska-Michalak (Eds.). Przywództwo edukacyjne $w$ teorii i praktyce. Warszawa: FRSE.

Madalińska-Michalak, J. (2014). Przywództwo w zarządzaniu szkołą. Retrieved from: http://www.bc.ore.edu.pl (10.10.2018). 
Mazurkiewicz, G. (2012). Przywództwo edukacyjne: kierunki myślenia o roli dyrektora. In G. Mazurkiewicz (Ed.). Jakość edukacji. Różnorodne perspektywy. Kraków: Wydawnictwo Uniwersytetu Jagiellońskiego.

Mazurkiewicz, G. (2015). Przywództwo edukacyjne. Zmiana paradygmatu. In G. Mazurkiewicz (Ed.). Przywództwo edukacyjne. Zaproszenie do dialogu. Kraków: Wydawnictwo Uniwersytetu Jagiellońskiego.

Mazurkiewicz, G. (Ed.) (2012). Edukacja i przywództwo. Modele mentalne jako bariery rozwoju. Kraków: Wydawnictwo Uniwersytetu Jagiellońskiego.

Moreira, M. A., Rivero, V. M. H., \& Alonso J. J. S. (2018). Leadership and school integration of ICT. Teachers perceptions in Spain. Education and information technologies, 24, 549-565.

Mrówka, R. (2001). Przywództwo w procesie planowania i wdrażania zmiany organizacyjnej. Warszawa: Warszawska Wyższa Szkoła Ekonomiczna.

Petlak, E. (2007). Klimat szkoły, klimat klasy. Warszawa: Wydawnictwo Akademickie „Żak”.

Pękala, J. L. (2017). Etos nauczycieli - mit czy rzeczywistość? Warszawa: Wydawnictwa Uniwersytetu Warszawskiego.

Pyżalski, J. (2015). Jestem tylko człowiekiem - jak dyrektor szkoły ma poradzić sobie z wymaganiami roli. In G. Mazurkiewicz (ed.). Przywództwo edukacyjne. Zaproszenie do dialogu. Kraków: Wydawnictwo Uniwersytetu Jagiellońskiego.

Pyżalski, J., Merecz, D. (2010). Stresory w środowisku pracy nauczyciela In J. Pyżalski \& D. Merecz (Eds.). Psychospołeczne warunki pracy polskich nauczycieli. Pomiędzy wsparciem zawodowym a zaangażowaniem. Kraków: Oficyna Wydawnicza „Impuls”.

Rosalska, M. (2016). Dyrektor szkoły: administrator, menedżer, przywódca: między szkolna codziennością a polityka oświatową. Poznań: Wydawnictwo Uniwersytetu im. Adama Mickiewicza.

Stefanik, M. (2012). Być liderem. In: G. Mazurkiewicz Ed.). Edukacja i przywództwo: modele mentalne jako bariery rozwoju. Poznań: Wydawnictwo Uniwersytetu im. Adama Mickiewicza.

Stefanowicz, B. (2010). Informacja. Warszawa: Warszawska Wyższa Szkoła Ekonomiczna

Szafran, J. (2013). Menadżer - przywódca. Uwagi o roli dyrektorów w zarządzaniu zmianami. Studia Edukacyjne, 27.

Tołwińska, B. (2011). Kierowanie szkołą: rola dyrektora - partycypacja nauczycieli. In S. M. Kwiatkowski, J. Madalińska-Michalak \& I. Nowosad (eds.). Przywództwo edukacyjne w szkole i jej otoczeniu. Warszawa: Difin.

Wenner, J. A., Cambell, T. (2017). The Theoretical and Empirical Basis of Teacher Leadership. A Review of the Literature. Review of Educational Research, 1(87), 134-171.

Zimbardo, P., Gerrig, R. (2012). Psychologia i życie. Warszawa: PWN. 


\section{PRZYWÓDZTWO W INSTYTUCJACH EDUKACYJNYCH: DZIELONE ZADANIE I WSPÓLNA ODPOWIEDZIALNOŚĆ}

Streszczenie: W obecnym świecie zmiany są nieuniknione i współczesne szkoły będą także nieustannie im podlegać. Dyrektorzy szkół powinni zatem zmierzać do przekształcania zarządzanych przez siebie placówek w organizacje uczące się, a więc gromadzące ludzi zdolnych do autorefleksji i samodoskonalenia. Celem niniejszego artykułu jest ukazanie, że aby osiągnąć wymierny i trwały sukces w placówce oświatowej, przywództwo musi być podzielone między dyrektora oraz nauczycieli. Ważne są także umiejętności diagnozy sytuacji placówki oraz wyciąganie konstruktywnych wniosków z wprowadzanych zmian, zarówno tych zakończonych sukcesem, jak i tych nieudanych. Znajomość możliwych stylów przywództwa może stanowić inspirację do poszukiwania skutecznych rozwiązań w praktyce edukacyjnej zarówno dla dyrektorów, nauczycieli, jak i zewnętrznych ekspertów udzielających szkołom wsparcia w procesie wprowadzania zmian.

Słowa kluczowe: przywództwo edukacyjne; zarządzanie oświatą; dyrektor szkoły; nauczyciel; organizacja ucząca się.

Joanna Ludwika Pękala - doktor nauk społecznych w dziedzinie pedagogiki, adiunkt w Zakładzie Wczesnej Edukacji i Kształcenia Nauczycieli na Wydziale Pedagogicznym Uniwersytetu Warszawskiego. Wieloletni nauczyciel edukacji wczesnoszkolnej i przedszkolnej. Zainteresowania badawcze autorki to pedeutologia, etyczne zagadnienia związane z pracą nauczyciela, kształcenie nauczycieli. Do wybranych publikacji należą: Teachers' ethos today: expectations and opinions (2018), Etos nauczycieli - mit czy rzeczywistość? (2017), Kompetencje etyczne nauczyciela (2017), Nauczyciele a rodzice - ioczekiwania i motywacje (2015), Nauczyciel dziś - pedagog czy edukator (2014), Dylematy współczesnego polskiego nauczyciela (2012). Adres do korespondencji: ul. Mokotowska 16/20, 00-561 Warszawa. Adres e-mailowy: jpekala@uw.edu.pl.

Wiktoria Kowalska - magister, doktorantka na Wydziale Pedagogicznym Uniwersytetu Warszawskiego. Zawodowo dyrektor akademickiego przedszkola Uniwersytetu Kardynała Stefana Wyszyńskiego w Warszawie. Zainteresowania naukowe i badawcze: szara strefa edukacji w Polsce, modele edukacji pozaszkolnej na świecie, współpraca z rodzicami i środowiskiem lokalnym w placówkach oświatowych. Wybrane publikacje: „Uniwersytet po Godzinach" - projekt łączący praktykę zawodową z teoria akademicką (2016); Społeczne postrzeganie szarej strefy edukacyjnej w Polsce i na świecie (2016). Adres do korespondencji: ul. Mokotowska 16/20, 00-561 Warszawa. Adres e-mmailowy: kowalskawp@gmail.com. 